\title{
Table of legal acts of the European Union
}

\section{COUNCIL REGULATIONS}

Council Regulation 19/65/EEC on the application of Article 85 (3) of the Treaty to certain categories of agreements and concerted practices, OJ 36, 6.3.1965, pp. 533-535 .158

Council Regulation (EU) No. 734/2013 of 22 July 2013 amending Council Regulation (EC) No. 659/1999 of 22 March 1999 laying down detailed rules for the application of Article 93 of the EC Treaty, OJ L 204, 31.7.2013, p. 15 166

Regulation (EC) No. 178/2002 of the European Parliament and of the Council of 28 January 2002 laying down the general principles and requirements of food law, establishing the European Food Safety Authority and laying down procedures in matters of food safety OJ L 31, 1.2.2002, pp. 1-24 240

Council Regulation (EC) No. 58/2003 of 19 December 2002 laying down the statute for executive agencies to be entrusted with certain tasks in the management of Community programmes, OJ L 11, 16.1.2003, pp. $1-8$ $.209,240$

Regulation (EC) No. 1/2003 of 16

December 2002 on the implementation of the rules on competition laid down in Articles 81 (now 101 TFEU) and 82 (now 102 TFEU) of the Treaty [2003] OJ L 1/1, as amended by
Regulation (EC) No. 411/2004 [2004] OJ L68/1 .........23, 61, 148, $157,171,172,174,176-179,181$, $182,213,214,234,340,347$

Council Regulation (EC) No. 139/2004 of 20 January 2004 on the control of concentrations between undertakings (the EC Merger Regulation), OJ L 24, 29.1.2004, pp. 1-22 ..160-163, 171, 172, 183, $185,303,310$

Regulation (EC) No. 1775/2005 of the European Parliament and of the Council of 28 September 2005 on conditions for access to the natural gas transmission networks (Text with EEA relevance), OJ L $289,3.11 .2005$, pp. 1-13 ........116, 118,231

Regulation (EC) No. 713/2009 of the European Parliament and of the Council of 13 July 2009 establishing an Agency for the Cooperation of Energy Regulators, OJ L 211, 14.8.2009, pp. $1-14 \ldots \ldots . .22,31,33,205,206$, 224-227, 235, 236, 238, 293, 298, 304,311

Regulation (EC) No. 715/2009 of the European Parliament and of the Council of 13 July 2009 on conditions for access to the natural gas transmission networks and repealing Regulation (EC) No. 1775/2005 of the European Parliament and of the Council of 28 September 2005 on conditions for access to the natural gas transmission networks, OJ L 211, 
14.8.2009, pp. 36-54 30-32, 72, 87, 103, 104, 112, 113 , 115-117, 120-124, 164, 205, 206, $211,219,225,226,231,236-238$, $291,303,308,313$

Regulation (EU) No. 994/2010 of the

European Parliament and of the Council of 20 October 2010 concerning measures to safeguard security of gas supply and repealing Council Directive 2004/ 67/EC, OJ L 295, 12.11.2010, pp. 1-22 .................4, 22, 30-32, 36-38, 87, 95, 111, 118-121, $125,135,141,212,225,236$, 249, 250, 292, 297, 303, 309

Regulation (EU) 1092/2010 of the European Parliament and of the Council of 24 November 2010 on European Union macro-prudential oversight of the financial system and establishing a European Systemic Risk Board, OJ L 331, 15.12.2010, pp. 1-11 .240

Regulation (EU) No. 1093/2010 of the European Parliament and of the Council of 24 November 2010 establishing a European

Supervisory Authority (European Banking Authority), amending Decision No. 716/2009/EC and repealing Commission Decision 2009/78/EC, OJ L 331, 15.12.2010, pp. 12-47 ....240, 243

Regulation (EU) No. 1094/2010 of the European Parliament and of the Council of 24 November 2010 establishing a European Supervisory Authority (European Insurance and Occupational Pensions Authority), amending Decision No. 716/2009/EC and repealing Commission Decision 2009/79/EC, OJ L 331, 15.12.2010, pp. 48-84 ....240, 243 Regulation (EU) No. 1095/2010 of the European Parliament and of the Council of 24 November 2010 establishing a European Supervisory Authority (European Securities and Markets Authority), amending Decision No. 716/ 2009/EC and repealing Commission Decision 2009/77/ EC, OJ L 331, 15.12.2010, pp. 84-119. 240,243

\section{COUNCIL DIRECTIVES}

\section{Council Directive 90/377/EEC of 29}

June 1990 concerning a

Community procedure to improve the transparency of gas and electricity prices charged to industrial end-users, OJ L 185, 17.7.1990, pp. 16-24... 20

Council Directive 91/296/EEC of 31 May 1991 on the transit of natural gas to grids, OJ L 147, 12.6.1991, pp. $37-40$ 20

Council Directive 93/13/EEC of 5 April 1993 on unfair terms in consumer contracts, OJ L 95, 21.4.1993, pp. 29-34 35

Directive 97/7/EC of the European Parliament and of the Council of 20 May 1997 on the protection of consumers in respect of distance contracts - Statement by the Council and the Parliament re Article 6(1) - Statement by the Commission re Article 3 (1), first indent, OJ L 144, 4.6.1997, pp. $19-27$ 35

Directive 1998/30/EC of the European Parliament and of the Council of 22 June 1998 concerning common rules for the internal market in natural gas, OJ L 204, 21.7.1998. pp. 1-2 195

Directive 2003/55/EC of the European Parliament and of the Council of 26 June 2003 concerning common rules for the internal market in 
natural gas and repealing Directive 1998/30/EC, OJ L 176, 15.7.2003, pp. $57-78 \ldots \ldots .27,31,34,146,150$, 195, 197, 222, 296, 301, 302, 307, $325,329,330$

Directive 2004/67/EC of 26 April 2004 concerning measures to safeguard security of natural gas supply (Text with EEA relevance), OJ L 295, 12.11.2010, pp. 1-22 171

Directive 2009/73/EC of the European Parliament and of the Council of 13 July 2009 concerning common rules for the internal market in natural gas and repealing Directive 2003/55/EC, OJ L 211, 14.8.2009, pp. $94-136$ 12,13 , 15, 22, 26-37, 44, 48, 68, 70-72, $86,95,97,99,103-105,108$, 110-112, 116, 118, 120-122, $125,132,134,141,143-151$, 165, 190, 191, 194, 205, 207, 210-212, 218, 219, 221-225, 235, 236, 242, 250, 252, 290, 297, 302, 303, 307, 312.

\section{COUNCIL DECISIONS}

\section{Council Decision 1999/468/EC laying} down the procedures for the exercise of implementing powers conferred on the Commission, OJ L 184, 17.7.1999, pp. 23-26

Decision No. 1364/2006/EC of the European Parliament and of the Council of 6 September 2006 laying down guidelines for trans-European energy networks and repealing Decision 96/391/EC and Decision No. 1229/2003/EC, OJ L 262, 22.9.2006 171

\section{COMMISSION} REGULATIONS

Commission Regulation (EC) No. 2790/1999/EC of 22 December 1999 on the application of Article 81 (3) of the Treaty to categories of vertical agreements and concerted practices, OJ L 336, 29.12.1999, pp. 21-25 158

Commission Regulation (EC) No. $2658 / 2000$ on the application of Article 81 (3) of the Treaty to categories of specialization agreements, OJ L 304, 5.12.2000, pp. 3-6

\section{COMMISSION DECISIONS}

Commission Decision 2000/45/EC of 29 September 1999 declaring a concentration to be compatible with the common market and the EEA Agreement (Case IV/M.1532 - BP Amoco/Arco) (Text with EEA relevance) (notified under document number C (1999) 3059), OJ L 18, 19.1.2001, pp. 1-17...163

Commission Decision 2003/796/EC of 11 November 2003 on Establishing the European Regulators Group for Electricity and Gas (Text with EEA relevance), OJ L 296, 14.11.2003, pp. 34-35 206

Exemption decision on the Austrian section of the Nabucco pipeline. Brussels, 8 February 2008 CAB D (2008) 142

Commission Decision of XXX on the exemption of an Underground Gas Storage Facility in Damborice, Czech Republic, from the internal market rules on third party access. Brussels 2011. Available at http:// ec.europa.eu/energy/ 
infrastructure/exemptions/doc/ doc/gas/2011_damborice_ decision_en.pdf 199

\section{COMMISSION DOCUMENTS}

\section{Green Papers and White Papers}

Commission White Paper on

Modernisation of the Rules

implementing articles 85 and 86 of the EC Treaty, OJ C132,

12.5.1999, p. 1

Green Paper - Towards a European strategy for the security of energy supply /*COM/2000/0769 final */, Brussels, 2000 141

Commission of the European Union, 2004: Green Paper on Services of General Interest. OJ C 76. 25.03.2004 .142

Green Paper A European Strategy for Sustainable, Competitive and Secure Energy /*COM/2006/105 final*/, Brussels, 8.3.2006 ........91, $131,134,136,249$

Green Paper on market-based instruments for environment and related policy purposes. /*COM/ 2007/140 final $* /$, Brussels, 28.3.2007

Green Paper on Consumers Collective Redress /*COM/2008/794 final*/, Brussels, 27.11.2008 23

White Paper on Damages Actions for Breach of the EC Antitrust Rules /*COM/2008/165 final/, Brussels, 2.4.2008 23,83

\section{Communications}

Communication from the Commission of 14 October 1998: Strengthening environmental integration within Community Energy Policy, /*COM/1998/0571*/. 138
Communication from the Commission to the Council, the European Parliament, the Economic and Social Committee and the Committee of the Regions on the Sixth environment action programme of the European Community "Environment 2010: Our future, our choice", /*COM/ 2001/31 final $* /$ 170

Communication from the Commission to the Council and the European Parliament The Energy Dialogue between the European Union and the Russian Federation between 2000 and 2004, /*COM/2004/777 final*/, Brussels, 13.12.2004 .....83

Communication from the Commission - Inquiry pursuant to Article 17 of Regulation (EC) No. 1/2003 into the European gas and electricity sectors (Final Report) /*COM/ 2006/851 final*/, Brussels, 10.1.2007

Communication from the Commission to the European Parliament, the Council, the European Economic and Social Committee and the Committee of the Regions Second Strategic Energy Review: and EU energy security and solidarity action plan /*COM /2008/0781 final*/, Brussels, 13.11.2008

Communication from the Commission Europe 2020 A strategy for smart, sustainable and inclusive growth /*COM/2010/2020 final*/, Brussels, 3.3.2010 125

Communication from the Commission to the European Parliament, the Council, the European Economic and Social Committee of the Regions: Energy Efficiency Plan /*COM/2011/109 final $* /$, Brussels, 8.3.2011 153 
Staff Working Documents, Reports and Impact Assessments

Report from the Commission - XXXth Report on competition policy 2000, /*SEC/2001/0694 final $* /$. 155

Commission Staff Working Paper First benchmarking report on the implementation of the internal electricity and gas market, $/ * \mathrm{SEC} /$ 2001/1957*/, Brussels, 3.12.2001 252,255

Commission Staff Working Document on capacity allocation and congestion management for access to the natural gas transmission networks regulated under Article 5 of Regulation (EC) No. 1775/2005 on conditions for access to the natural gas transmission networks, /*SEC/2007/822*/, Brussels, 12.6.2007. 116,118

Commission Staff Working Document accompanying the

Communication from the Commission - Inquiry pursuant to Article 17 of Regulation (EC) No. 1/2003 into the European gas and electricity sectors (Final Report) $\{\operatorname{COM}(2006) 851$ final $\}, / *$ SEC/ 2006/1724 - Vol. I, II, III, IV*/, Brussels, 10.1.2007 188

DG Competition Report on Energy Sector Inquiry, /*SEC/2006/ 1724/, Brussels, 10.1.2007....6, 22, $96,114,222$

Commission Staff Working Document Accompanying the legislative package on the internal market for electricity and gas. Impact Assessment, /*SEC/2007/1179/, Brussels, 19.9.2007.....28, 29, 192,

194,216

Commission Staff Working Document accompanying the Communication from the Commission to the European
Parliament, the Council, the European Economic and Social Committee and the Committee of the Regions Second Strategic Energy Review An EU energy security and solidarity action plan Europe's current and future energy position Demand - resources investments \{COM (2008) 781 final $\}$ S SEC(2008) 2870 $\}$ $\{$ SEC(2008) 2872\}/*SEC/2008/ $2871 * /$, Brussels, 13.11.2008 ..135

Commission Staff Working Document Accompanying document to the Proposal for a Regulation of the European Parliament and of the Council concerning measures to safeguard security of gas supply and repealing Directive 2004/ 67/EC The January 2009 Gas Supply Disruption to the EU: An Assessment, /*SEC/2009/977 final*/, Brussels 16.7.2009 ........24

Commission Staff Working Paper Interpretative Note on Directive 2009/72/EC Concerning Common Rules for the Internal Market in Electricity and Directive 2009/ 73/EC Concerning Common Rules for the Internal Market in Natural Gas The Unbundling Regime. Brussels, 22.1.2010 ....72,

Commission Staff Working Paper An Energy Policy for Consumers, /*SEC/2010/1407 final*/,

Brussels, 11.11.2010 153

Commission Staff Working Document 2009-2010 Report on progress in creating the internal gas and electricity market. Brussels, 9.6.2011 205,210

Commission Staff Working Document public consultation: Towards a Coherent European Approach to Collective Redress, /*SEC/2011/ 173 final $* /$. 
PREPARATORY ACTS OF THE EUROPEAN UNION

Commission of the European Communities Amended Proposals for a European Parliament and Council Directive on common rules for the internal market in gas, /*COM/93/643 final - 1993/0385/ COD*/ 42

Proposal for a Directive of the European Parliament and of the Council amending Directives 96/92/EC and 98/30/EC concerning common rules for the internal market in electricity and natural gas, /*COM/2001/125 final 2001/0077/COD*/

Proposal for a Regulation of the European Parliament and of the
Council on guidelines for trans-European energy infrastructure and repealing Decision No. 1364/2006/EC /*COM/2011/0658 final - 2011/ 0300/COD*/ 125,126

Proposal for a Directive of the European Parliament and of the Council amending Directive 2003/55/EC concerning common rules for the internal market in natural gas \{SEC(2007) 1179\} \{SEC (2007 $1180) / * \mathrm{COM} / 2007 / 0529$ final $-2007 / 0196 /$ COD $* /$ .27

European Parliament resolution of 10 July 2007 on prospects for the internal gas and electricity market, OJ C 175 E, 20087 10, p. $206 \ldots . .28$ 
Monica Waloszyk - 9781783473472 Downloaded from PubFactory at 04/26/2023 10:16:24AM via free access 